\title{
Is Zaynab Alkali Merely A Feminist Writer? An Appraisal Of The Stillborn And The Virtuous Woman
}

\author{
Amase, Emmanuel Lanior (Corresponding author) \\ Federal University Dutsin-ma, Nigeria \\ E-mail: eamase@fudutsinma.edu.ng \\ Tsavmbu, Aondover Alexis \\ Federal University Dutsin-ma, Nigeria \\ E-mail: atsavmbu@fudutsinma.edu.ng \\ Kaan, Aondover Theophilus \\ Federal University Dutsin-ma, Nigeria \\ E-mail: akaa@fudutsinma.edu.ng
}

Received: 09-010-2013

doi:10.7575/aiac.ijalel.v.3n.3p.188
Accepted: 11-02-2014

Published: 01-05-2014

URL: http://dx.doi.org/10.7575/aiac.ijalel.v.3n.3p.188

\begin{abstract}
Many African literary critics seem to have some preconceived notions about female writers. Consequently, there has been indiscriminate branding of some female writers either as feminists or female chauvinists. This portrays them as incapable of addressing other topical issues of national interest other than those that affect the women directly. In this paper therefore, we have undertaken an appraisal of Zainab Alkali's The Stillborn and The Virtuous Woman to buttress our position that the issues in her novels transcend gender imbalance. The paper examines Alkal's treatment of the clash of westernisation, tradition and city life, political mal-administration, poor infrastructure as well as the challenging environment of the emerging cities. These are issues, which we believe, affect both male and female. The paper advocates a broader look at texts rather than the emphasis on the feminist angle in the interpretation of works by female authors at the expense of probably more important issues.
\end{abstract}

Keywords: Feminism, Feminists, gender, culture

\section{Introduction}

There is a disturbing trend in African literary criticism particularly in Nigeria that has seriously compromised the contribution of female writers to the development of literature on the continent: the indiscriminate branding of female writers as feminists regardless of the main thematic thrusts of their works. Whenever, a work that carries a female authorial signature hits the literary scene, some critics are quick to banish such a work to the feminist fold without digging deeply to ascertain whether or not they are intended to serve more pluralistic purposes. Sometimes, this happens to the consternation of the writers themselves as Azuike has pointed out, "In Nigeria, our pioneer female writers such as Flora Nwapa, BuchiEmecheta and Ifeoma Okoye, to mention a few, have severally denied having anything to do with the ideology of feminism.... Similarly, Zaynab Alkali easily denies that she is a feminist." (Azuike 2003:3) Despite these objections from our frontline female writers, the feminist brand dogs their works regardless of whether or not there is enough material in the texts in question to sufficiently validate such claims. In a good number of the cases, apologists of feminist literature squeeze the content of works authored by female writers to fit into predetermined feminist constructs.

The questions one would therefore ask are: is it not possible for any Nigerian female writer to pursue themes of universal appeal? If we answer this question in the affirmative, perhaps we will also be interested in unraveling the rationale for the rather undue emphasis on the feminist angle in the interpretation of works by female authors at the expense of probably more important issues that more often than not remain unattended to in such works. If the contrary is the case, that is to say if one denies that female writers are capable of raising any issues other than those bordering on the perceived marginalization, oppression, denigration, etc. of the womenfolk in their works, then the logical conclusion would be that such a position would be too juvenile and pedestrian to merit any serious attention as it would go a long way to support the deep seethed sentiments against which feminists have generally fought: the perceived superiority of male folk over their female counterparts.

It is against this backdrop that one identifies the necessity of re-examining the works of Nigerian female writers along more generic criterion with the view to determining whether or not in our haste to label every creative material by our female writers as feminist literature we have, perhaps, overlooked one or two issues of no mean significance. For this purpose therefore, we have chosen to beam our searchlight on Zaynab Alkali, a prolific Nigerian female writer, who has persistently rejected her being classified as feminist albeit with little or no success. In doing this, we have elected to use two of her most popular works, The Stillborn and The Virtuous Woman. 


\section{Who Is A Feminist Writer?}

According to Allison (2013), it is a dangerous game asking what feminist literature is or feminist anything for that matter since feminism is a self-defined term; that anyone who proposes to have the correct definition of feminism is a liar. After sounding this note of warning, which one would do well to heed, Allison goes ahead to suggest that "feminist literature presents female characters with faculties, desires, aggressions, lusts, and conflicts. They are the mistresses of their own destinies: making their choices and playing their hands while telling their own stories and engaging us, the readers, in their extraordinary journeys" (Allison 2013: 1).

Although no definition is without shortcomings, in this essay, this is our understanding of feminist literature and that includes all kinds of literature jostling for recognition under this nomenclature such as "liberal feminism, radical feminism, Marxist feminism, socialist feminism, cultural feminism, black/African feminism, womanism, African womanism, stewanism, and motherism", which have been painstakingly reviewed by Azuike (2003: 23 - 39). Apparently therefore, this understanding of feminist literature places Alkali's The Stillborn and The Virtuous Woman within the feminist fold, for in these two novels are found strong female characters such as Li, Awa, Faku, Grandmother, etc. and Nana Ai, Laila and Hajjo for The Stillborn and The Virtuous Woman respectively. These are female characters whose characterization negates the stereotypical roles ascribed to females by the male dominated world.

In The Stillborn particularly, we observe the unique qualities of $\mathrm{Li}$, one of the major characters, right from the beginning. Though her school mates are happy at the prospect of returning home after the successful completion of a school year, we are told that "Li felt alone although she was among friends and age-mates, none of whom was much older than herself" (Alkali 1984: 1) and wonders if something is wrong with her. Even at home, she "felt trapped and unhappy. Already she missed the kind of life she had lived at the primary boarding school, free and gay. At home the little ones were too young to understand the restrictions and the older ones too dull to react. They all seemed to accept the situation as natural..." (Alkali 1984:3)We are therefore not surprised when Li becomes a catalyst that encourages her elder sister, Awa, and her friend, Faku, to break the strict code that threatens their full integration into the social life of their cultural milieu by, among other acts frowned against by their father, sneaking to traditional dances and being so forward in the courtship of Habu Adams, the man of her dream contrary to the norms of her society. It is little wonder then that later in life, once $\mathrm{Li}$ and Faku discover that their aspirations cannot find full expression within the confines of their marriage relationships, they break loose and become success stories on their own. In other words, these characters have taken their destinies into their hands; a trait common with feminist works of art.

A similar scenario of strong female characters plays itself out in The Virtuous Woman through the depiction of Nana Ai, Laila and Hajjo: three young ladies who have defied traditional beliefs on the position of the woman in the kitchen in her husband's house where she is expected to produce as many children as possible and satisfy all his whims and caprices. In this novel, we see a parent expressing pride at the success story of his daughters, "My daughter and granddaughter are wonderful children." (Alkali 1985: 3) The pride this parent feels at his daughter and granddaughter gaining admission into the prestigious Queen's College coupled with similar achievements by another girl in the village, Nana Ai, four years earlier and the gratitude of their parents goes a long way to portray a society that has accepted a woman's ability to operate at par with her male counterpart in society as can be discerned from their meeting, journey, friendship and intimacy with Bello and Abubakar, students from King's College. The spirit of friendship that transpires between the girls and the boys is shown to be devoid of the usual inferiority complex that characterises women in similar company. This depiction of boys and girls operating at same level in pursuit of opportunities hitherto considered the exclusive preserve of males is so beautifully done that the report of Dogo's male chauvinistic statements must be understood as vestiges of a past that should be best forgotten. A close perusal of the novel actually shows a society that does not reinforce such strong sentiments Dogo Expresses:

What is the use of sending a female child to school? If she turns out well, the man she marries gets the benefit of her education. If she gets spoilt in the school, I get the blame. It's my name that gets dragged into the mud. It's my house that becomes her refuge. Whichever way you look at it, the father of a female child is the loser. Let the girls stay at home and help their mother; when it is time for them to marry, let them marry. (Alkali 1985: 47)

Even the way Dogo ends up in life can be attributable to the result of his holding onto archaic sentiments that clearly belong to the past.

\section{Are Zaynab Alkali's The Stillborn and The Virtuous Woman Feminist Novels?}

When viewed from the above perspectives, one can say both The Stillborn and The Virtuous Woman are feminist novels and the writer, Zaynab Alkali, is a feminist: case closed. But would such a position not be too hasty, simplistic and bereft of more objective perusal of the novels? Could the presentation of female characters in these novels really be the exclusive criterion for making such weighty value judgment considering the negative connotations that the term feminist evokes in a male dominated world? When one reads Chinua Achebe's Anthills of the Savannah and sees the portrayal of strong female characters like Beatrice and Elewa and what they do: how Beatrice surpassed the best of the best in the most prestigious British university and came home with a first class honours degree; how she not only rejects the cultural perception on marriage but chooses her own man (Chris Oriko) and enjoys premarital sex with him on her own terms in her own apartment; how both Beatrice and Elewa actively facilitate Chris Oriko's escape from His Excellency's hired guns completely indifferent to fears for their own lives; how Beatrice not only takes care of Elewa, Ikem Osodi's pregnant woman, after Ikem's murder but also performs the naming ceremony in her apartment and gives the child a name, a male name. We can see that the depiction of female characters in Achebe's Anthills of the Savannah is remarkably more impressive than that of their male counterparts: Chris Oriko, Ikem Osodi and His Excellency. This explains why the male characters are finally destroyed by circumstances of their own making, with Beatrice, Elewa and the newly born baby girl remaining the only men standing. 
The question is, does this portrayal of female characters place Achebe within the feminist fold or has he escaped this classification by virtue of his biological attributes? Another way of putting this question is has the statement Achebe made in Anthills of the Savannah about the role of women in our modern world compromised his main thematic thrust, which is indisputably the malady of military dictatorship in Nigeria? If we answer No! to this last question, is it, therefore, not possible that just as Achebe has done in Anthills of the Savannah, Zaynab Alkali has used her female characters for the attainment of an agenda greater than some feminist vendetta her gender might nurse with the larger society? Cannot one prove that Alkali's works, particularly the ones being discussed presently, are not merely about the womenfolk but that the female characters in The Stillborn and The Virtuous Woman are just what they are - characters and used as foils for espousing some higher ideals beneficial to humanity generally? If this scenario is possible as the material in these novels suggests, then we must expunge Zaynab Alkali's name from the purview of what Azuike calls "radical feminist writers" (Azuike 2003: 1) and redirect our energies to exhuming the main issues in her works particularly, The Stillborn and The Virtuous Woman; issues that our rather hasty sex based judgment has interred.

\section{The Stillborn}

A close perusal of The Stillborn shows that beyond the garb of feminism with which the novel has been adorned, a situation similar to what happens in Chinua Achebe's Things Fall Apart when different value-systems clash has taken place. But unlike in Achebe's novel where the clash is between tradition and westernization, the situation in Alkali's The Stillborn is a bit more complex as the novel presents a multiple clash of values involving tradition, westernization and city life, with city life being a hybrid of tradition and westernisation. Lucid examination of the key characters reveals that westernization is reflected in $\mathrm{Li}$, Awa, Habu and Fiama who is also called HM. Faku represents tradition while Garba and "the woman from the south" represent city life. This classification is substantiated using the views of these characters on the issue of marriage: Li, Awa, Fiama and Habu, due to their exposure to western education, conceive marriage from the westernized perspective of a happy union between one man and one woman; where both work for the success of the matrimonial home and live happily ever after in love as encapsulated in Li's thoughts:

She was going to be a successful Grade I teacher and Habu a famous medical doctor, like the white men in the village mission hospital. The image of a big European house full of houseboys and maids rose before her. Li smiled to herself. The bushy stream, the thorny hillside and the dusty market would soon be forgotten in the past. (Alkali 1984: 55)

Garba and the "woman from the south" believe neither in monogamy nor love! For them, one gets a partner so the partner may "slave" for him or her. As far as these two characters are concerned therefore, marriage is just another game of survival like any other thing in the city. That is why the "woman from the south" takes advantage of Habu's naivety, trapping him into a relationship that produces disastrous consequences for both of them. It is this same attitude towards marriage that is echoed by Garba as the virtues of city life when he says:

Getting marriage is not expensive in the city, brothers...A girl could live with you of her own free will. Sometimes you do not have to pay anything....In the city you do not have to live together in the same house. I have a friend who keeps four women in four different areas of the city. None of them knows the others exist(s) and they slave for him! (Alkali 1984: 44 - 45)

However, based on their background and upbringing, it is not surprising that Li, Awa, Habu and HM see this perception as an affront on their value system and therefore condemn Garba's idea of marriage without reticence. Their condemnation of such a practice, which to them is an aberration both from the traditional and the Christian points of view, is captured in Awa's denunciatory remark, "That is not marriage...That's prostitution!" (Alkali 1984: 45).HM supports Awa by saying "It is no way to live' (Alkali 1984: 45) while Habu asks "How can he love all of them"? (Alkali 1984: 45)

Faku on her part does not see anything wrong with what Garba advocates. Not being as educated as her friends, she believes in the traditional marriage arrangement where a man takes more than one wife. We are told that, "Faku, however, thought quite differently. What was this love the rest were cracking their heads about? When a man cared for his family, fed and clothed them properly, what was it if it wasn't love?" (Alkali 1984: 46) But she is clearly too ignorant to realise that what Garba advocates is the opposite of the traditional polygamous marriage system where a man marries many wives and provides for them equally. Little does she know that, as far as Garba is concerned, even the traditional marriage practice that she appears comfortable with is a product of lack of civilization just as the idea of a monogamous marriage based on love espoused by $\mathrm{Li}$, Awa, Habu and HM is for him a figment of misguided imaginations:

Haba Habu....Book learning has ruined you. It is a good thing my old woman never sent me to school. What is this love you talk about, friend? Can a man possess a lot? Come brothers, listen to me... I did not live in the city for nothing. I know a bit about the world, more than our fathers who were born and brought up in this small village. There are a lot of things about the city I cannot talk about, simply because such things have no place in the village. But you are young and will soon go out into the world. Only then would you learn from time and experience. Right now you do not believe me, but it does not matter. Some day you will find out I was telling the truth (Alkali 1984: 45) We can therefore see that three value systems - westernization, tradition and city life - are on a collision course in this novel thus setting the stage for the conflicts we encounter. It is significant to note that marriage or man-womanrelationship generally has not been used in this novel as an end in itself. For Alkali, marriage is a symbol that gives physical shape to the sharp contrast in the sets of values jostling for attention in our emerging cities. What the author is saying is that those who can survive in the emerging cities of Africa must not jettison their cultural teachings completely; neither should they hold onto the old ways dogmatically. Rather, those who will survive in the emerging cities must examine qualities of both, retain the positives and discard the negatives. This is what characters like Sule, Faku, Li and Audu's son have done in the novel and that is why they have succeeded at the end despite the fact that their initial dreams may have been stillborn: They conjure up new dreams that are more in line with the realities of the 
day and see them through. Their successes contrast with Garba's failure as he has not got the benefit of the sound cultural upbringing having been taken to the city as a child.

This thematic thrust is consistent with happenings in emerging Nigerian cities at the time this novel was written; a time when the African culture was experiencing onslaughts from foreign cultures; attacks that more often than not, led made many youths to become disorientated, disenchanted and lose grip on life. Clearly therefore, we can see that the key issue in Alkali's The Stillborn transcends gender imbalance. The issue treated here is of general significance, affecting both male and female alike. The dreams of the key characters remain stillborn because the characters, both male and female, seek the realisation of their dreams within a setting controlled by unfamiliar dynamics that are not complementary to what they know and seek. Given this situation, their dreams must remain stillborn, at least until, like $\mathrm{Li}$, Faku, and Sule eventually do, they learn to marry the two sets of values positively: jettisoning the negatives and keeping the positives.

Sule has demonstrated the ability to do this. Although he allowed Garba's stories about city life to lure him into acts that ultimately make a fugitive of him, he learns the hard way and becomes successful later in life. When he meets Li after disappearing for many years, he narrates his tale of woes thus:

I stole out of this country under a false name and without papers. For two years I travelled from one country to another under different names. As for jobs I have done everything - legal and illegal. I have been arrested more than once, but always acquitted. Now I wonder how I managed to escape a prison sentence. (Alkali 1984: 98)

It is significant that Sule attributes his success to the sound training given to him by their father. "The experience(s) I had, taught me a lot of things about life. It softened my heart towards my father. I can now understand why he was obsessed with discipline. I could have ended up in prison, Li, but for the conscience my father instilled in me" (Alkali 1984: 100). This underscores the necessity to allow the new city ways of life to complement but never to substitute the sound moral background inculcated into one. This is the roadmap to success in the challenging environment of the emerging cities being expounded by Alkali.

Apart from Garba whose lopsided development allows the forces of success in the emerging cities to overwhelm and completely annihilate his dreams, HM has equally been overwhelmed and totally eclipsed by city life. HM and Awa, his wife, had refused to go to the city reasoning that the city would eventually come to them and they were right in that. Awa expresses these sentiments to her sister when she says:

Yes, daughter-of-my-mother, we need not go to the city. The city will come to us. The government will soon take over all schools and hospitals. That means rapid development. A secondary school will be attached to the primary school and HM will be the first principal. The last time the Primary School Inspector came, he as good as told him so. The HM promised me an important position in the school. I will be head of the Adult Education Classes for older women. (Alkali 1984: 56)

However, HM and Awa fail to take into cognizance the fact that to survive in the city requires a new set of skills. When asked what has brought about the negative changes in her husband, Awa responds:

I don't know, Li, but I think many things helped to change my man. The village itself changed and he changed with it. The government took over the mission school just as we had hoped. A secondary school was added to it. But it wasn't my man they made head over the school. So a stranger was brought to take his place. This time a brown man. He wasn't even white, Li. Not the white people we are used to in the village. My man was pushed into the junior classes to teach. Those of us that could barely read were asked to work anywhere in the school except the classrooms. The men have no choice. Most of them have grown too stiff in the waist to till their ancestral lands, so, they were content to sweep the offices and run errands, jobs their women and small children do at home (Alkali 1984: 87)

Faku's experience of city life is not better either. When Li goes to see her, we are told that:

She could not believe this was reality. How could this near-stranger be her friend Faku? Famished in body and no doubt famished in soul? The house was filled with tiny feet, running in and out of the outer room, but no feet came into Faku's room. She looked round the tiny outer room. There wasn't much in it, two old arm-chairs, a small wooden table, some tattered mats and a half-filled glass cupboard. (Alkali 1984: 77)

It is significant that Faku refuses to complain about her situation, neither blaming her husband who is similarly blown here and there by the wind of city life nor blaming her co-wife who has mastered the survival techniques and is obviously faring much better. Faku has learnt that in the city what one becomes depends on his or her actions or inactions. That is why she also decides to take her destiny into her hands and finally becomes a success story.

$\mathrm{Li}$ and Habu go through the same experiences as the other characters presented above. When Li goes to town to meet her husband, after four years of being abandoned in the village, she meets a totally different Habu:

She bent her head and hot tears trickled down her cheeks. 'Where is my man?' she wailed, silently, 'That boyish man with an incredible smile and a mischievous twinkle in the eye? Where is that proud, self-confident, half-naked lover that defied the laughter of the villagers and walked the length and breadth of the village just to see me? (Alkali 1984: 70)

Although at this time Li does not understand the changes that have come over her man, she is later to discover that Habu Adams is equally a victim of city life which according to her "...destroys dreams" (Alkali 1984: 94). She learns how her then innocent man had been trapped by a more experienced "woman from the south" (Alkali 1984: 91) who took advantage of his ignorance on his arrival in the city. "They worked in the same office. It was when Habu was new in the city and was a bit awkward, but she showed him round, cooked for him and was generally helpful. The friendship went too far and she found herself with child..." (Alkali 1984: 91) As Li goes ahead to relate the circumstances that led 
to Habu's enslavement to this "woman from the south", one cannot help sympathizing with Habu who had abandoned the valuable wisdom his background had inculcated into him from birth pursuant to the ephemeral affairs of the city.

This shows that what Alkali has captured here is not as simple as that of one sex oppressing the other as diehard feminists would want us to believe. On the contrary, the author shows deep understanding of challenges of city life; a life in which to survive, one does not have to plunge in headlong, obliterating all the virtues he had acquired from his traditional background, but to acquire whatever the new way of life has that can complement the old and enable him to grow. That is why Li does not feel bitter towards the "woman from the south" and refuses to blame her for apparently misguiding Habu saying, "this is a game of life and we are all struggling to survive" (Alkali 1984: 93). It is this realisation that makes Li go back to her husband in the city notwithstanding the fact that Habu has become not just emotionally but physically lame, rationalizing her decision thus: "We are all lame, daughter-of-my-mother. But this is not time to crawl. It is time to learn to walk again." (Alkali 1984: 105)

Another character, simply described as Audu's son, has also mastered techniques of coping with city life. When the rain of life beats him too strongly, he settles for any decent work rather than submit himself to crime and criminality like many youths in his position would have done. Here is another example of one that has blended the wisdom of traditional life in the challenges of city life; he too is a lesson for the youth. Audu, his father, ignorantly laments, "Don't talk to me about my son in the city! The city may be big but not my son. Like a woman, he cooks for the big men in the city.....Yes, cooks, son-of-my-mother. What other dirty jobs he does for them I do not know. All I know is that every other year, he comes home hungry-looking and loaded with problems..." (Alkali 1984: 49) What Audu does not know is that city life is different from village life and one has to survive through any means he can. He ought to have been grateful that his son has not taken to vice but has chosen to live decently.

The discussion so far shows that Zaynab Alkali's The Stillborn is not just about the woman question; in fact, if the key preoccupation of this writer were to propagate feminist propaganda, she would not have fore-grounded Grandma in the story. Grandma is in every way the opposite of the other admirable female characters in the novel:

Shrewd and dominating, she had driven three other wives from the household and had ruled father and son with an iron hand. It was rumoured that she had been divorced three times by Kaka but each time had refused to leave. She had remained immovable in the family and every mishap was blamed on her presence. Li liked her funny stories but disliked her dirty habits and foul language. Somehow she was glad Grandma wasn't a blood relation. (Alkali 1984: 8)

Grandma is also not beyond extorting money from her own granddaughter through cheap blackmail apart from the fact that she takes pride in her sex appeal! "My breasts were the size of backyard pumpkins and my buttocks the envy of the village maidens. The men could not resist me. You know I have been married fourteen times, and each time..." (Alkali 1984: 35) Feminist writers do not emphasise these qualities in their quest for equality with men as they believe that aside these physical attributes of their gender, a woman can still hold her own against a man any time any day. The point here is that if this novel were essentially a feminist novel and Alkali merely a feminist writer and nothing else, such a character as Grandma, who contrasts so sharply with Grandpa or Kaka, would not have merited a place in the novel.

\section{The Virtuous Woman}

In The Virtuous Woman also, this same conclusion can be drawn. In fact, evidence that would indict Alkali of feminism is sparser in this novel than in The Stillborn. This novel can best be described as protest against all sorts of vices constituting a bane to the progress of Nigeria. Right from the beginning of the novel we hear Alkali speaking strongly against sentiments of class consciousness that have become the bane of development in our country. When for instance Hajjo and Laila get selected to attend Queen's College, the Chief protests:

My daughters... deserve a place in the college of the woman-chief-of-the-whites. What business have the children of a common man like Boni ... in the college of the chief where only the children of the rich, those of royal blood, high ranking officials and politicians are taken? (Alkali 1985: 3)

The chief does not only stop at this but orders the headmaster to go and effect the change and only relents when he discovers it is impossible to carry out the injustice. Such things are happening in our society on a daily basis. People get admissions and jobs based not on what but who they know. Even within family settings, such segregation is not uncommon as we see from Hajjo's experience, "Twice, her grandmother in intense anger, had beaten her on the head and had called her a bastard. In the school, she had come to know, through some envious classmates, that she was the product of 'a street affair."' (Alkali 1985: 7)However, Hajjo does not allow these disparaging and debasing remarks to discourage her. We know that when writers bring out such issues in their works, they are making a statement to society against such practices and this issue is no exception. Therefore, anyone who ignores this cogent lesson in preference to gender issues has not placed his priorities correctly as far as the interpretation of this novel is concerned.

Apart from the above, the male characters, unlike what obtains in most feminist literature, have been presented excellently. Apart from Dogo, all the other male characters do not display any feeling of male chauvinism as it is common with feminist works of art. Right from the beginning of the novel, we encounter Boni who cannot hide his pride at his daughter's and granddaughter's achievement as he openly brags, "my daughter and granddaughter are wonderful children." (Alkali 1985: 3) We also encounter Nana Ai's grandfather who appears to live only for his granddaughter. The narrator tells us that:

Some people said he was a hard man, devoid of human feelings.... Only the child knew her grandfather well enough to see past the iron cast of his self control, to the slow, deep stream of love and tranquility that ran beneath. He possessed wisdom that surpassed the understanding of a child, and Nana sometimes wished there were others to partake of his close teachings. (Alkali 1985: 12-13)

This type of characterization of the male gender in The Virtuous Woman makes it hard for one to accept that the novel is feminist propaganda. Even when one considers the younger male characters such as Abubakar and Bello, the King's College students who later travel with the three girls, it is hard to notice any other sentiments than civilised conduct in 
the way they present themselves. On the contrary, it is the female characters that are shown to revel in petty jealousy of their fellow females; particularly towards Nana Ai whom they envy as can be seen by the conduct of the girl Nana fights at the fountain when she goes to wash her cloths. The girl insinuates that Nana Ai is not good enough to have gotten admission into the prestigious Queen's College without getting assistance from her grandfather: "You know better than I do, Nana Ai. A daft girl, like wayward goat, does not get admission into the best secondary school in the North just like that"(Alkali 1985: 16) and the attitude of Laila towards Nana Ai.

Alkali also uses this novel to condemn poor work attitude by civil servants while at the same time attacking those in leadership positions for not doing what they are supposed to do to make life bearable for the people. First of all when Nana, Hajjo, Laila, Bello and Abubakar go to the secretariat to find out if the secretary is on duty so they can get their transport fare and escort for the journey back to school, the man is not on duty and the place is deserted. This is how Abubakar expresses disgust at this kind of behaviour, "Nine o'clock, and a government official is still snoring in his harem." (Alkali 1985: 28). Even the clerk does not come until after twelve noon to inform them that, "you see, ... the man is on a three-day tour, but has been absent for six days. That's what they do, the so called big men." (Alkali 1985: 29) The entire atmosphere at this secretariat depicts a people that are not serious with the work for which they are employed to do. When Nana Ai and her companions approach the receptionist at the first instance, "the clerk looked up briefly, her eyes full of hostility. She summed Nana up at a glance and went back to trimming her nails. Nana wondered what she had done to deserve such cold treatment." (Alkali 1985: 29) Alkali is thus making a statement about poor ethics in Nigeria; that our country cannot record any appreciable progress with people taking their jobs for granted as this secretary and her boss have done in this novel.

At the accident scene, Alkali also makes a statement about the obsolete and inhuman nature of laws of the land. We are told that after loading the accident victims on the remaining lorry:

A man in a grey suit pointed out that they shouldn't even move the injured without police escort. The argument went forward and backward fruitlessly, until an old man asked if they had to remain helpless and watch people die because of some stupid law. He turned angrily to the man in the grey suit and asked him, not too gently, to provide them with a policeman, assume the role of one, or shut his big mouth (Alkali 1985: 65)

This is protest against the inhuman nature of our legal system which our security personnel are simply too pleased to enforce. The attitude of the policeman the travellers meet at the check point shortly after is typical of this situation. Immediately he sees the accident victims, he exclaims, "Oh God... what is this? You should have taken a policeman with you" (Alkali 1985: 68). He then insists on making a report thus delaying the travellers but when he discovers that two of the injured persons have already died while he procrastinates, the policeman panics and lets the vehicle through in that typical fashion of not wanting to take responsibility for a problem that has become characteristic of our police personnel.

But the biggest protest Alkali makes in this novel is done through Bello who is one of the most impressive characters in the novel. After the series of accidents they experience on their journey during which several people die including Abubakar, Bello's friend, Nana Ai calls on God to have mercy, only for Bello to respond:

No, Nana, we will have to have mercy on ourselves first. God has other priorities that to help a nation that is bent on destroying itself... I never used to care that the roads were bad, until now. The few tarred ones are not maintained; dangerous potholes and jagged edges have become the order of the day. By God, such roads are worse than the tarred ones. Then behind the wheels, what have you?....Reckless, in-disciplined and unqualified drivers, who should not be on the road, but who somehow got their driving licenses even before they had touched a steering wheel. On the road, a kola here, a kola there, and the law enforcement agency is crippled. The result is always the same countless broken hearts and homes, children turned orphans overnight, old people with non to give them a befitting burial, a large family without a head, the list endless. And why? Just because a handful of greedy and corrupt people in places of authority have failed to place God on their priority list.... I don't know, Nana. I don't claim to know the answer. But this I know: something has got to be done, and fast too, otherwise as a nation we are in trouble. It is no fit place where the young die and leave the old. (Alkali 1985: 79-80)

The above treatise is an indictment of Nigerian leadership beginning from the top executives who are supposed to take decisions that would rid the nation of killer roads to the technocrats in offices and law enforcers who unleash suicidal drivers that ought to be in psychiatric homes on our roads; clearly caring more about the sizes of their wallets than the welfare of the helpless common man who places his life in the hands of such inept, incompetent and mentally imbalanced drivers. Alkali also condemns the followership for their role in the malady of maladministration that is a recurrent decimal of our national life as she points out how the passengers remain silent and in fact applaud the reckless drivers when any right thinking people should actually collectively call the errant drivers to order like the teacher, who appears to be the only mentally balanced person in this confusion, does from time to time.

The exposition we have in this novel, far from exclusively confining itself to feminist preoccupations, is the loudest form of protest. Protest against all manner of discriminatory tendencies in our society, particularly discrimination on the grounds of class or social standing; protest against poor attitude to work as exemplified in the clerk and her boss at the secretariat; protest against criminal negligence of duties on the part of our leaders; protest against bribery and corruption, which resultant effect is loss of valuable lives that ought to have contributed to the greatness of the nation; protest against a blind followership that indulges in grotesquely insane ululation of acts they should deprecate in the strongest terms possible. What the author has done in this novel is to awaken the slumbering, dead, interred and even decayed conscience of a people that is precariously edging towards obliteration due to all manner of self-inflicted injury. 


\section{Conclusion}

Zaynab alkali is a prolific Nigerian novelist who understands commitment to her society and by so doing demonstrates Achebe's belief that the novelist is a teacher. We cannot condemn her masterpieces to the abyss of feminist creativity as many critics have, in our opinion, erroneously done; rather, we should consider Alkali as a committed writer that addresses germane issues crying for attention in her society, including but not exclusively confined to feminist issues just as Achebe has done in Anthills of the Savannah. This is what every creative writer who is conscious of his duty to society does since literary works are neither mere displays of fertile imagination nor the isolated caprices of excited brains. Creative writers transcribe contemporary manners and customs with the view to pointing society towards the right direction for the benefit, not just of a segment of the society as feminist apologists do, but for that of all and this is what Alkali has done in her works particularly The Stillborn and The Virtuous Woman as we have seen in the above expose.

\section{References}

Achebe C. (2000). Anthills of the Savannah. Heinemann Educational Books (Nigeria) Plc.

Alkali, Z. (1984). The Stillborn. Lagos, Longman.

(1985). The Virtuous Woman. Nigeria, Longman.

Allison, J (2013). "What Is Feminist Literature?" Posted on Jan 17, 2011 in Feminism, Gender, Literature http://www.talesofthepack.com/about-3/about-tales-of-the-pack/copyright-policy/ accessed Wednesday $3^{\text {rd }} \mathrm{July}, 2013$.

Azuike, M. N. (2003). "A Radical Feminist Approach to the Works of Zaynab Alkali". A Thesis in the Department of English, University of Jos - Nigeria, December. 